\title{
Social Enterprise Development-oriented Poverty Alleviation and Sustainable Development of Relative Poverty Groups in Rural Areas
}

\author{
Xing Jianye \\ College of Marxism, Xiamen University, 361005 Xiamen Fujian, China.
}

\begin{abstract}
The relative poverty groups in rural areas have become main target of China's poverty alleviation andto explore a long-term effective alleviation mechanismis now a significant topic for research. After thorough research, this paper examines the status and role of this new social organization in rural development-oriented poverty alleviation with the example of the self-service agencies in Xiapu County and Fu'an City founded by the China Foundation for Poverty Alleviation. These social enterprises could improve production and living conditions of relative poverty groups and plays an irreplaceable role in the new rural construction; therefore the government should support the development of social enterprises with proper policies and financial support.
\end{abstract}

Keywords. social enterprise; development-oriented poverty alleviation; sustainable development

\section{Introduction}

As the society develops, Chinese government has achieved some major changes in the poverty alleviation. Firstly, the target has shifted from the absolute poverty population only to both the absolute and the relative poverty. The absolute poverty population has reduced by over 200 million since 1978. Based on the two-phase theory of poverty, the major problem was the absolute poverty in China before 2000; yet after 2000, the relative poverty becomes the main concern (Shihong Yin, 1998; Qingxia Zhang, 2008). Secondly, the measures being taken to lift poverty now include not only providing relief but also developing the poor regions. In 2008, the central government set the overall guidance to support the low-income through both development and social relief. Thirdly, non-governmental and governmental organizations now are also contributing to the cause. Some traditional departments gradually transformed to social enterprises and they are now an indispensable part in poverty alleviation.

Indeed, tremendous progress has achieved, China still faces tough challenges. First, China has a large poverty population. China still has a poverty population of over 100 million in rural areas based on the latest standard (a net income of RMB2300). Second, there is a wider gap between the rich and the poor. While the number of the absolute poverty decreases, the issue of relative poverty in rural area stands out ${ }^{1}$ Third, the development is unbalanced. The poorest areas are mainly the minority and the border areas in the west, the old revolution bases and the mountainous areas in the middle part and

\footnotetext{
${ }^{1}$ Absolute poverty refers to the situation that the earnings is not enough for the minimum life needs. Relative poverty refers to the low-income group who are capable to improve the living standards through work.
} 
the inland areas in the east. It is thus important to target the right group, reasonably utilize the resources, innovate the mode and increase the efficiency.

So far, quite a few development-oriented modes have been proven effective. Taking rural area's characteristics into consideration, China Foundation of Poverty Alleviation (CFPA) followed the example of Grameen Bank and successfully launched the micro-finance program. Early this century, cooperating with local governments, CFPA established more than 60 self-service agencies (hereafter the agency), providing micro-finance programs to relative poor in rural area. Two agencies (one in Fu'an and the other in Xiapu, both Fujian Province) are most typical either in terms of their developments, operation patterns or the achievement. Therefore, the author will further analyze these two agencies to exam the indispensable role of the development-oriented poverty alleviation.

\section{Development}

Fu'an and Xiapu both lay in the northeast part of Fujian province. Due to the poor transportation system and the coastal defense in this area, these two towns are still quite backward compared to the developed areas. Fu'an covers an area of 1,880 square meters with the coastal line stretching 68.5 kilometers. The whole city has 11 counties, 7 villages, 3 streets, 447 districts and 42 resident's committees. By 2007 , the city has over 600,000 people and roughly 160,000 households, among which 491,397 are farmers and 108,116 households are peasant households, accounting for $82 \%$ and $67.1 \%$ respectively. Fu'an is the biggest gathering place for the She minority in China. More than 60,000 She people live in Fu'an. Land area in Fu'an totals 2.82 million mu, mountainous area 2.266 million mu, water area 227,000 $\mathrm{mu}$, and cultivated area 326,000 mu. Xiapu Town covers a land area of 1682.91 square meters, a sea area of 28,900 square meters and a 404-meter-long coastline. The whole town can be further divided into 12 counties, 2 streets and 315 districts. By 2007, the total population reached 514,200 , among which 443,800 was agricultural population. Population with ethnical minority background is 47,000 .

After the eight-year large scale poverty reduction (1986 1994) and the Seven-Year Priority Poverty Alleviation Program (1994 2001), the poverty issue has been somewhat eased in these two areas, but it is far from being completely solved. It is estimated that 15,447 people in Xiapu only earned less than RMB1,000 in 2005 which was not enough for basic needs, and another 22,335 people earned1,000 1,500, just enough for food. Likewise, over 8,889 people's net income was under 1,100 in Fu'an in 2007, and 52,065 lived with an income between 1,100 and1,500. The low-income population (per capita $1,500 \sim 1,800$ yuan) was 108,160 that year. ${ }^{2}$.

Initial capital is the major obstacle for the sustainable development for the relative poor groups. These farm households rarely have the chance to get the loan from financial institutes since most of them live in remote areas. Besides, most poor farm households cannot provide any pledge but they are desperately in need of fund during farming seasons. Therefore, traditional financial agencies cannot meet their needs. To solve these problems and under the guidance of Online on Poverty Alleviation in Rural China, in the December of 2001, Fu'an municipal government, Fujian provincial poverty alleviation office and CFPA jointly established Fu'an Self-Service Agency, launching micro-finance programs for poor farming households. Similarly, Xiapu also established Xiapu Self-Service Agency in August, 2003. They were among CFPA's 7 piloting areas at that time.

After the establishment, both agencies have undergone two transformations. Before June 2005, the service was carried out in the form of projects. It was a combination of governmental and intermediary organization which took the advantages of both. The entity of poverty alleviation was slightly shifted from the government to social enterprises. Registered in local civil affairs office, the agency would receive capital from the provincial office and CFPA would later instruct the projects. However, the capital was limited. They only had 5 million invested by the provincial office in the form of soft loans. Therefore, fewer funds were lent at that moment (table1, 2).Then in June, 2005,

\footnotetext{
${ }^{2}$ All statistics in this paper is based on author's research to the self-service agencies in Fu' an and Xiapu in Fujian province.
} 
Fu'an and Xiapu agency officially transformed to CFPA's subdivisions, with the director of CFPA poverty alleviation department being the legal person. Then CFPA quickly expanded its investments in these two agencies via commercial banking loans. CFPA invested 7 million in Fu'an in 2007 (CDB loan) and another 6.5 million in 2008 (SCB loan). It increased its investment in Xiapu agency by 5 million for three consecutive years from 2005. The capital totaled 17 million by 2007 . The amount of loans also grew speedily.

On November 18th, 2008, CFPA once again transformed its micro-finance program department to a program management limited company. Fu'an and Xiapu agencies thus became the company's branch offices. After the transformation, CFPA has been more supportive than ever to all agencies in terms of financing. Xiapu agency will borrow roughly 6 million from CFPA one month or two before the spring festival every year. The capital available is now about 23 to 24 million. As for Fu'an, Fu'an municipal government invests 10 million to the agency every year since 2011. Currently, the agency has a fixed capital of over 28 million. With additional help for CFPA time to time, Fu'an agency can possess as much as 45 to 46 million at disposal.

The business may still under government's supervision, but the entity has changed from government to social enterprises. It allows the low-income to have the access to initial capital, so that micro-business programs can be further developed. Meanwhile, the agency also needs to account independently to maintain its own sustainable development. Now, Fu'an and Xiapu agencies have 18 and 16 employees respectively. As a social enterprise, this agency is different from Grameen Bank. The latter one is established independently by social entrepreneurs and the fund was raised by them; while the former one is the combination of government and non-governmental organizations. Its capital mainly comes from the government, donations and the bank. Yet, both serve to help the poor and the low-income.

\section{Achievement over the past decade}

Both agencies adhere to CFPA's operation mode and focus. They take the local situation into account, target at the relative poor farming households and achieve great success.

\subsection{The amount of loan increases steadily}

Since 2002, the total lending and the total amount of loan in Fu'an have both expanded gradually (table1). Compared with Fu'an, Xiapu has a quite different path of development. It has been shifting its focus from group lending to personal loan since May, 2009. Hence, the total lending in Xiapu remains basically unchanged, yet the total amount of loan and the amount of each loan are both growing dramatically (table2,table4). The accumulate amount of loan totals RMB2.6744 trillion in Fu'an, RMB2.2909 trillion in Xiapu by 2012.

Table 1. Annual total amount of loan in Fu'an agency (2002 2012)

\begin{tabular}{|c|c|c|c|c|c|c|c|c|c|c|c|}
\hline Year & $\mathbf{2 0 0 2}$ & $\mathbf{2 0 0 3}$ & $\mathbf{2 0 0 4}$ & $\mathbf{2 0 0 5}$ & $\mathbf{2 0 0 6}$ & $\mathbf{2 0 0 7}$ & $\mathbf{2 0 0 8}$ & $\mathbf{2 0 0 9}$ & $\mathbf{2 0 1 0}$ & $\mathbf{2 0 1 1}$ & $\mathbf{2 0 1 2}$ \\
\hline Total lending & 2560 & 2687 & 2880 & 2956 & 3217 & 3560 & 4112 & 4126 & 4201 & 4568 & 4588 \\
\hline $\begin{array}{c}\text { Total Amount of loans } \\
\text { (RMB/million yuan) }\end{array}$ & 3.548 & 5.44 & 6.572 & 7.0565 & 11.2685 & 23.744 & 35.5164 & 35.663 & 37.266 & 48.637 & 52.73 \\
\hline $\begin{array}{c}\text { Average amount of each } \\
\text { loan(RMB/yuan) }\end{array}$ & 1385 & 2025 & 2292 & 2387 & 3503 & 6670 & 8637 & 8643 & 8869 & 10647 & 11493 \\
\hline
\end{tabular}

\subsection{Constant innovation of loan product}


Table 3 and table 4 show clearly the development of the loan limits in the two agencies. Take Fu'an as an example, the limit has undergone 6 different periods. The group loan limit has increased from RMB3,000 to 12,000. In 2010 the agency launched two personal guaranteed loan products which can borrow as much as RMB 30,000 and RMB 50,000 respectively according to credit rate. While Xiapu usually alternately promotes different loan products and always takes the initiative to try on new products. The products in Xiapu have two major changes: the first is the limit increased in each loan and the second is the launch of personal guaranteed product. Micro-finance program used to be mainly aimed for peasant households in rural areas, but after 2008, urban farming households can also apply for the program.

\subsection{An expanded group of service objects}

The service objects broadened in both agencies. Take Fu'an for instance, in the early period, the agency mainly served the families in poverty and low-income families whose per capita net incomes are less than RMB 1,200 or between RMB 1,200 and 1,500 per year respectively. In this period, the micro-capital projects concentrated on 10 least developed towns and villages. Among the total 5,800 households applied for the loan, over 1000 have ethnic minority background (Guowang Liu, 2004:26). By the end of June, 2009, the programs have covered over 343 villages and 166 districts from 17 towns (ShoumingZheng, 2010:32).By May of 2012, the accumulative loan have totaled RMB 2.40618trillion covering 5,0562 households from 379 villages and 205 districts from 18 towns. The population benefiting from 98 programs reached 236,000, including 35\% minorities and 20\% from old revolution bases. Xiapu's main target has altered from mountainous areas to coastal villages.

Table 2. Annual total amount of loan in Xiapu agency (2003 2012)

\begin{tabular}{|c|c|c|c|c|c|c|c|c|c|c|}
\hline Year & $\mathbf{2 0 0 3}$ & $\mathbf{2 0 0 4}$ & $\mathbf{2 0 0 5}$ & $\mathbf{2 0 0 6}$ & $\mathbf{2 0 0 7}$ & $\mathbf{2 0 0 8}$ & $\mathbf{2 0 0 9}$ & $\mathbf{2 0 1 0}$ & $\mathbf{2 0 1 1}$ & $\mathbf{2 0 1 2}$ \\
\hline Total lending & 1109 & 3862 & 4110 & 5193 & 7391 & 8816 & 3493 & 2013 & 1837 & 1840 \\
\hline $\begin{array}{c}\text { Total Amount of loans } \\
\text { (RMB/million yuan) }\end{array}$ & 1.109 & 5.738 & 8.3824 & 11.7991 & 23.178 & 34.18 & 22.941 & 33.355 & 42.408 & 46.00 \\
\hline $\begin{array}{c}\text { Average amount of each } \\
\text { loan(RMB/yuan) }\end{array}$ & 1000 & 1486 & 2040 & 2272 & 3136 & 3877 & 6566 & 16570 & 23085 & 25000 \\
\hline
\end{tabular}

Table 3. Change of loan limits of different credit rate in Fu'an agency (RMB/yuan)

\begin{tabular}{|c|c|c|}
\hline \multirow{3}{*}{$\begin{array}{c}1^{\text {st }} \text { Period } \\
(2002.1 \sim 2006.8 .30)\end{array}$} & Rate1 & 1000 \\
\hline & Rate2 & 2000 \\
\hline & Rate3 & 3000 \\
\hline \multirow{3}{*}{$\begin{array}{c}2^{\text {nd }} \text { Period } \\
(2006.9 .1 \sim 2007.7 .31)\end{array}$} & Rate1 & 1500 \\
\hline & Rate2 & 2500 \\
\hline & Rate3 & 3000 \\
\hline \multirow{2}{*}{$\begin{array}{c}3^{\text {rd }} \text { Peroid } \\
(2007.8 .1 \sim 2009.4 .30)\end{array}$} & Rate1 & 4000 \\
\hline & Rate2 & 7000 \\
\hline
\end{tabular}


IFSRAP 2013

\begin{tabular}{|c|c|c|}
\hline \multirow{3}{*}{$\begin{array}{c}4^{\text {th }} \text { Period } \\
(2009.5 .1 \sim 2010.11 .8)\end{array}$} & Rate3 & 10000 \\
\cline { 2 - 3 } & Rate1 & 6000 \\
\cline { 2 - 3 } & Rate2 & 8000 \\
\hline \multirow{2}{*}{$\begin{array}{c}5^{\text {th }} \text { Period } \\
(\text { since } 2010.11 .9)\end{array}$} & Rate3 & 10000 \\
\cline { 2 - 3 } $\begin{array}{c}\text { Personal guaranteed loan } \\
(\text { starting from 2010) }\end{array}$ & Rate1 & 8000 \\
\cline { 2 - 3 } & Rate2 & 12000 \\
\hline
\end{tabular}

Table 4. Change of loan limits of different credit rate in Xiapu agency (RMB/yuan)

\begin{tabular}{|c|c|c|}
\hline \multirow{3}{*}{$\begin{array}{l}2003.8 \sim 2004.6 \\
\text { (group loan) }\end{array}$} & Rate1 & 1000 \\
\hline & Rate2 & 2000 \\
\hline & Rate3 & 3000 \\
\hline \multirow{3}{*}{$\begin{array}{l}\text { 2004.6 2005.10 } \\
\text { (group loan) }\end{array}$} & Rate1 & 1500 \\
\hline & Rate2 & 2000 \\
\hline & Rate3 & 3000 \\
\hline \multirow{2}{*}{$\begin{array}{l}2005.10 \sim 2009.5 \\
\text { (group loan) }\end{array}$} & Rate1 & $3000 \sim 5000$ \\
\hline & Rate2 & $5000 \sim 8000$ \\
\hline $\begin{array}{c}2005.10 \sim 2009.7 \\
\text { (group loan, pay back at one time) }\end{array}$ & $\begin{array}{l}\text { One-time payment with time limit as } \\
\text { either } 6 \text { months or } 10 \text { months }\end{array}$ & $1000 \sim 5000$ \\
\hline \multirow{3}{*}{$\begin{array}{l}\text { Since } 2008.6 \\
\text { (group loan, pay back monthly with } \\
\text { interest) }\end{array}$} & Rate1 & 3000 \\
\hline & Rate2 & 6000 \\
\hline & Rate3 & 9000 \\
\hline \multirow{3}{*}{$\begin{array}{c}\text { Since 2009.5 (personal guaranteed } \\
\text { loan) }\end{array}$} & Rate1 & 10000 \\
\hline & Rate2 & 30000 \\
\hline & Rate3 & 50000 \\
\hline
\end{tabular}

Currently, $80 \%$ of the total capital goes to the low-income families in coastal counties. By 2012 , more than 50,000 people from 10,650 households benefit from the programs, covering 60 villages, 181 districts and 13 towns. 


\section{Success factors}

Why can the micro-finance program achieve such good results and be so popular among the relative poor farming households?

\subsection{Participatory development principal}

The agency is a very good implementation of participatory development. Each agency is running by itself, which transforms the goal into people's internal needs. Specifically speaking, firstly, each agency recruits its own employees whose job is to instruct its members to choose the suitable micro projects to expand their production, and organize mutual aid group in which members can help with and provide advice for each other. Then pick 4 to 7 members to form the joint guarantee group. Secondly, members can apply for loans and once the application approved by the agency, the applicant can receive the money directly. The lending principal is small amount, instalment repayment. Besides, if 5 households are jointly guaranteed for the applicant, collateral won't be necessary. Then based on the situation of the project and repay, applicants will be rated as first, second and third rate. The higher the applicant is rated, the more he can borrow in one single loan. Thirdly, lectures and trainings have been given to farmers to teach them more about the micro-finance, basic legal knowledgeand practical skills. Forms of these lectures and trainings vary, including multimedia teaching, inviting professional technicians to give the lectures, etc.

Shi-kun Lei is a good example. Lei lives in a small village in Fu'an. This village, with over 110 households, is a gathering village for She minority group. It used to be a blind zone for bank loan due to the inconvenient transportation. Lei's family once stayed in the primary school. Since he is the only labor force in his family and the farming is very toilsome, Lei was addicted to gambling and drinking. When the micro-finance program is available, he was thinking about raising pigs. In 2002, Lei received 3000yuan, his first loan $^{3}$. He spent 2000 yuan and bought 6 pigs. What's more, he also received some related information together with the fund. These information has been very helpful to him and he later attended local agricultural to learn the skills to raise pigs. Then in 2010, Lei started to raise Rex Rabbits and went to veterinary station to study how to better raise rabbits. Under his influence, about 10 people in the village started to raise rabbits and chickens, and 20 raise pigs. In 2010, Lei made a fortune and spent 140,000 yuan to build a two-storey house. Apart from doing business, Lei also cares for the charity, now he is elected as the Party Branch Secretary in his village.

\subsection{An acquaintance society based credit system}

Compared with traditional micro-finance programs, the agency has a better basis of credit--the acquaintance society.

Firstly, all the employees in the agency are local people who speak same language and share same social, economic and cultural background with the members. This is not only the foundation to carry out all the publicizing and mobilization work, but also the premise to establish the micro-finance credit system. Secondly, the joint guarantee group consists of 4 to 7 households. To team up with who is completely up to their own choice. Since these households in the same village are all very familiar with each other, those bad-credit households would have been eliminated in the first place because the members in the same group should be able to face common risks and assume common responsibility. In addition, local customs also play important role when it comes to repayment. Thirdly, the director of the agency is usually those with high integrity in the village. The employee will take director's opinion into consideration when choosing clients, which has further lower the risk. In personal guaranteed loan, it is required by CFPA that a co-borrower is needed besides the guarantee. The co-borrower can be spouse, siblings or other relatives.

\footnotetext{
${ }^{3}$ At that time, the agency has over 70 members. Now more than 60 households are still working with the agency, including Lei's family.
} 
The credit system based on the acquaintance society complies with the situation in the rural China. It promotes the program and also improves the credit environment. Paying back by month and forming a joint guarantee group are a strengthening of their credit consciousness. They have gradually developed the good habit of careful calculation and strict budgeting. In Xiapu, the credit consciousness of most farmers have enhanced so greatly that some local traditional financial institutes even fight with the agency over clients.

\subsection{Rely on local economy}

Relying on the local economy is another important factor. Most projects are connected to the local economy. In Fu'an, the most advanced industries include electronic machine and ship. Industries like tea, grape cultivation, aquaculture, and animal husbandry are all very popular now. When choosing project, farmers tend to rely on local economy. Among the 14 counties in Xiapu, 8 of them are near the sea. Therefore, aquaculture (seaweed, fish, sea cucumber etc.) is important to Xiapu's economy. In Dong'an village in Xiapu, over 500 households raise seaweed. In 2004, most seaweed seedlings dead, and the agency release 1500 yuan each households for more than 270 households to buy new seedling so that the production were not affected.

The program also promotes the local economy. More than $99 \%$ micro-finance projects succeed in Xiapu, covering planting, breeding and service industries. The total earning for the low-income increased more than 100 million yuan. Besides, those projects gave birth to a bunch of specialized households.

\section{Conclusion}

The popularity of these micro-finance programs in Fu'an and Xiapu shows the fact that most peasant households in rural areas are short of capital. Most of them need to raise money for next year's production around the spring festival every year. A popular saying goes like this: "To get money at the end of the year is as impossible as to see snow in summer" which vividly describes the shortage of transitional funds. Every spring festival is the busiest time. $80 \%$ to $90 \%$ of businesses are done within the last month of the year. During the survey, most farmers strongly suggest raise the amount of loans. The central government has been constantly promoting the financial innovation in rural areas. Yet, few have taken effect so far. For example, many village banks and micro-finance companies have been set up in Wenzhou and Taizhou, Zhejiang province. However, most of these are personal banks (Caiyong Zhou, 2013). These agencies are "external finance"4. In a long time to come, capital shortage will remain to be the developing bottleneck for the relative poverty groups in rural areas.

Currently, the central government is increasing its investment in poverty alleviation, but the investment is too disperse and inefficient. Also the funds seldom invest in production. Hence local governments should adopt an opener and more innovative perspective.

Review the experiences, conclusion can be safely reached that targeting the relative poverty groups, strengthening the intervention towards related financial projects, supporting the development of such social enterprises as the "self-service agency" and forming a long term mechanism of poverty alleviation in rural China should be the main goals for the government's poverty alleviation efforts.

\section{References}

1. Carl Borzaga and Jacques Defourny. The Emergence of Social Enterprise[M]. London \& New York: Routleedge, 2001.

\footnotetext{
${ }^{4}$ External finance refers to the financial programs which farmers have no control of over interest and other, the otherwise called internal finance. Rural financial innovation should develop the internal finance. (Chang-ping Li, 2012)
} 
2. Shaohao Gan. How to improve the self-sustainability of NGO's micro-finance program-Research on the self-service agency in Xiapu[J]. Changsha: Finance and Economy. 2005 (5).

3. Guowang Liu. Use 1000 yuan to open the deadlock-Records of the development of micro-finance programs in the piloting self-service agencies in Fu'an and Xiapu[J].Western Finance and Accounting. 2004.

4. Xiaojuan Pan. Primary expoloration of the social enterprises[J]. China Public Administration. 2011(7).

5. Xiaolong Wen. Establish self-service agency to tap the new path for poverty alleviation[J]. Beijing. Financial View. 2008(2).

6. Shouming Zheng. Zixing $\mathrm{Wu}$. Jingping Chen. The defects and improvement measures of micro-finance organization in rural area[J]. Fujian Finance. 2010(7).

7. 2011 CFPA Annual Report on Micro-finance Program[Z].2011.

8. Caiyong Zhou. Practice and Reflections of the rural financial innovation in Taizhou, Zhejiang province[J]. Rual Work Communicate. 2013(1).

9. Shihong Yin. Poverty in China's Urban Areas[M].Jiangxi Renmin Press.1998.

10. Yearbook of China's Poverty Alleviation and Development (2010 to 2011)[Z].

11. China National Bureau of Statistics. Poverty Monitoring Report of Rural China(2009)[Z].

12. Changping Li. Tell the Truth to Premier II [M]. China Fortune Press. 2012 